\title{
Cancer in young people in the north of England, 1968-85: analysis by census wards
}

Alan W Craft, Louise Parker, Stan Openshaw, Martin Charlton, James Newell, Jill M Birch, Val Blair

\begin{abstract}
Objective-To determine whether the seeming excess of childhood leukaemia and lymphoma identified in Seascale, Cumbria, UK, remains unusual when put into a wider context.
\end{abstract}

Design-Analysis of cancer incidence by geographical area.

Setting-The north of England including the Northern and North Western Regional Health Authority regions and the Southport and South Sefton districts of the Mersey Regional Health Authority.

Subjects-Altogether 6686 cases of malignant disease in people under 25 years old.

Measurements and main results-Cases of cancer diagnosed before their 25th birthday between January 1968 and December 1985 identified from three regional cancer registries were allocated to a census ward on the basis of 'usual place of residence'. Population data were derived from the 1971 and 1981 censuses, and the cancer incidence was calculated for each ward. Of the 6686 cases, there were 1035 cases of acute lymphoblastic leukaemia and 361 of non-Hodgkins lymphoma. Wards were ranked by cancer incidence and Poisson probability, using different population bases. Seascale ward is the most highly ranked ward for acute lymphoblastic leukaemia for the time periods 1968-85 or 1968-76. It is not the most highly ranked for non-Hodgkins lymphoma. However, combining acute lymphoblastic leukaemia and non-Hodgkins lymphoma incidence gives an even more extreme position for Seascale. The most extreme Poisson probability for any of the analyses was that for brain tumours in the electoral ward of Ashton St Michael, Tameside ( $p=0.000009)$. Conclusion-The incidence of acute lymphoblastic leukaemia and non-Hodgkins lymphoma in the Seascale ward remains high when put into a wider context. For other cancers there are wards with even more extreme Poisson probability values.

f Epidemiol Community Health 1993; 47: 109-115

The seeming excess of cancer in young people on the Cumbrian coast identified in 1983 by Yorkshire Television in a documentary entitled, Windscale: the nuclear laundry led the government to set up an independent inquiry under the chairmanship of Sir Douglas Black. The report of this advisory group ${ }^{1}$ concluded that there did seem to be an excess of leukaemia in young people in some villages, particularly Seascale, near to the Sellafield nuclear installation, and that they could find no biological explanation for this when known radiation exposures were taken into consideration. The Black report made a number of recommendations for further study, the results of which have been published. These include a Seascale birth cohort study, ${ }^{2}$ a Seascale school cohort study, ${ }^{3}$ and a case-control study of leukaemia and lymphoma in west Cumbria. ${ }^{4}$ The cohort studies have confirmed an increased risk of leukaemia in those children born in Seascale but not in those who attended school in the district of Seascale but were born elsewhere. The case-control study of leukaemia and lymphoma has pointed to an increased risk for the children of workers employed at the nuclear installation at Sellafield who were exposed to relatively high doses of radiation. In addition recommendation 4 stated:

'The Northern Children's Cancer Registry should be asked to analyse their data using 1961, 1971 and 1981 population census data where appropriate. Also stratification for age at diagnosis and grouping by census ward at birth (as well as at diagnosis) should be undertaken, to determine the contribution these factors make to the incidence of leukaemia at Seascale.'

The data supplied to the Black enquiry from the Northern Region Children's Malignant Disease Registry were those for 1968-82, using 1981 census population data for children diagnosed before their 15 th birthday. The purpose of recommendation 4 was to put the apparent excess of leukaemia in Seascale into a wider context and in consultation with the Department of Health and Social Security it was decided to extend further the recommendation to include data from the Manchester Children's Tumor Registry and to obtain information for all young people diagnosed as having cancer before their 25 th birthday. It was also agreed to include the Southport and South Sefton districts of the Mersey health region so that the whole of the coastline from the Solway to the Mersey could be included.

Seascale is an electoral ward and by analysing cancer incidence data by electoral ward for the whole of the Northern and North Western Regional Health Authorities plus the two Mersey health districts the relative importance of the apparent excess described in the Black report could be explored.

\section{Methods}

CANCER REGISTRATION DATA

Cases of cancer in young people diagnosed between January 1968 and December 1985 were ascertained from existing cancer registries. The 
0-14 year old children from the northern region were obtained from the Northern Region Children's Malignant Disease Registry which was established in $1968^{5}$ and for the north west region from the Manchester Children's Tumour Registry, established in $1953 .{ }^{6}$ Both registries have a high level of case ascertainment, estimated at greater than $98 \%$, and there is extensive cross checking with other data sources. All cases have central pathological review. The 15-24 year old cases from the northern and north western regions were obtained from the relevant regional cancer registries. The registries contribute their data to the national cancer registration system. Ascertainment is thought to be in the region of $94 \%$ for all ages but is likely to be better for younger people. $^{7}$ All cases from $0-24$ years for the two Mersey districts were ascertained from the Mersey Regional Cancer Registry.

Patients included were all those with malignant disease receiving their first treatment, or having the diagnosis confirmed if no treatment given, before their 25 th birthday. Those with benign or borderline intracranial or intraspinal neoplasms were included but carcinoma in situ of the cervix was excluded. The National Health Service was reorganised in 1974 and regional administrative borders changed. The geographical boundaries of this study were therefore taken as those areas common to the pre-1974 Newcastle and Man-

Table I Number of cases by registry, agc group (y), and disease category

\begin{tabular}{|c|c|c|c|c|c|}
\hline \multirow[b]{2}{*}{ Diagnosis } & \multicolumn{2}{|c|}{$\begin{array}{l}\text { Age groups (y) } \\
\text { in Newcastle } \\
\text { registry }\end{array}$} & \multicolumn{3}{|c|}{$\begin{array}{l}\text { Age groups (y) } \\
\text { in Manchester } \\
\text { registry }\end{array}$} \\
\hline & $0-14$ & $15-24$ & $0-14$ & $15-24$ & Total \\
\hline Acute lymphoblastic leukaimia & 359 & 81 & 459 & 136 & 1035 \\
\hline Acute myeloid leukemia & 66 & 59 & 83 & 103 & 311 \\
\hline Chronic myeloid leukaemia & 7 & 13 & 13 & 24 & 57 \\
\hline Other leukaemia & 4 & 9 & 9 & 15 & 37 \\
\hline Astrocytoma/glioma & 156 & 108 & 192 & 122 & 578 \\
\hline Medulloblastoma & 61 & 13 & 88 & 15 & 177 \\
\hline Ependymoma & 30 & 14 & 48 & 16 & 108 \\
\hline Craniopharyngioma & 19 & 17 & 19 & 12 & 67 \\
\hline Other brain & 25 & 57 & 26 & 44 & 152 \\
\hline Osteosarcoma & 40 & 40 & 44 & 61 & 185 \\
\hline Ewing's sarcoma & 22 & 26 & 27 & 34 & 109 \\
\hline Other bone & 3 & 11 & 7 & 17 & 38 \\
\hline Non-Hodgkin's lymphoma & 76 & 73 & 95 & 117 & 361 \\
\hline Hodgkin's lymphoma & 56 & 285 & 72 & 353 & 766 \\
\hline Wilms' tumour & 71 & - & 94 & 14 & 179 \\
\hline Neuroblastoma & 71 & 4 & 100 & 6 & 181 \\
\hline Ganglioneuroblastoma & 5 & 1 & 2 & - & 8 \\
\hline Retinoblastoma & 48 & - & $4 \overline{1}$ & - & 89 \\
\hline Rhabdomyosarcoma & 54 & 11 & 57 & 20 & 142 \\
\hline Other soft tissue sarcoma & 20 & 51 & 21 & 71 & 163 \\
\hline Hepatoblastoma & 7 & 3 & 10 & 1 & 21 \\
\hline Germ cell tumours & 31 & 111 & 63 & 198 & 403 \\
\hline Miscellaneous & 104 & 440 & 191 & 784 & 1519 \\
\hline Total & 1335 & 1427 & 1761 & 2163 & 6686 \\
\hline
\end{tabular}

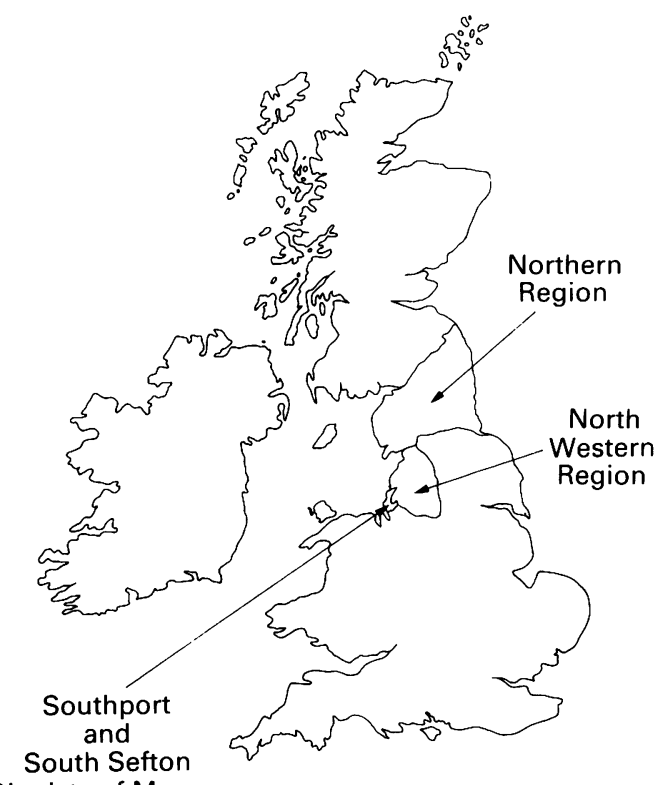

Districts of Mersey

Region

Table II Poisson probability ranking: all cancers, 1981 census population data

\begin{tabular}{|c|c|c|c|c|}
\hline \multirow[b]{2}{*}{ Ward name } & \multicolumn{2}{|c|}{ Numbers } & \multicolumn{2}{|c|}{ Statistics } \\
\hline & $P$ & $C$ & Rate $^{*}$ & Probability \\
\hline $\begin{array}{l}\text { Aged 0-24 y, 1968-85: } \\
\text { Kendal Fell, South Lakeland, Cumbria } \\
\text { Central Bolton, Greater Manchester } \\
\text { Prudhoe South, Tynedale, Northumberland } \\
\text { John O'Gaunt, Lancaster, Lancashire } \\
\text { Beswick, Manchester, Greater Manchester }\end{array}$ & $\begin{array}{r}526 \\
4698 \\
1374 \\
2347 \\
3492\end{array}$ & $\begin{array}{r}7 \\
24 \\
11 \\
15 \\
19\end{array}$ & $\begin{array}{l}5 \cdot 8 \\
2 \cdot 2 \\
3 \cdot 5 \\
2 \cdot 8 \\
2 \cdot 4\end{array}$ & $\begin{array}{l}.0002610 \\
.0003544 \\
.0004430 \\
.0004881 \\
.0006681\end{array}$ \\
\hline $\begin{array}{l}\text { Aged } 0-14 \text { y, 1968-85: } \\
\text { Seascale, Copeland, Cumbria } \\
\text { Easterside, Middlesbrough, Cleveland } \\
\text { No 6. Sedgefield, Durham } \\
\text { Kendall Fell, South Lakeland, Cumbria } \\
\text { Prudhoe South, Tynedale, Northumberland }\end{array}$ & $\begin{array}{r}411 \\
1021 \\
600 \\
267 \\
676\end{array}$ & $\begin{array}{l}6 \\
8 \\
6 \\
4 \\
6\end{array}$ & $\begin{array}{l}6 \cdot 9 \\
3 \cdot 7 \\
4 \cdot 7 \\
7 \cdot 1 \\
4 \cdot 2\end{array}$ & $\begin{array}{l}\cdot 0002804 \\
\cdot 0017235 \\
\cdot 0019432 \\
\cdot 0026720 \\
.0034776\end{array}$ \\
\hline $\begin{array}{l}\text { Aged 15-24 y, 1968-85: } \\
\text { Central, Bolton, Greater Manchester } \\
\text { Longhorsley, Castle Morpeth, Northumberland } \\
\text { No 6, Salford, Greater Manchester } \\
\text { Newcastle upon Tyne (Moorside), Newcastle upon Tyne } \\
\text { Newcastle upon Tyne (Jesmond), Newcastle upon Tyne }\end{array}$ & $\begin{array}{r}1914 \\
169 \\
2735 \\
1479 \\
1655\end{array}$ & $\begin{array}{r}15 \\
4 \\
18 \\
12 \\
12\end{array}$ & $\begin{array}{l}2 \cdot 6 \\
7 \cdot 9 \\
2 \cdot 2 \\
2 \cdot 7 \\
2 \cdot 4\end{array}$ & $\begin{array}{r}\cdot 0009149 \\
.0018409 \\
.0020805 \\
\cdot 0021456 \\
\cdot 0051662\end{array}$ \\
\hline $\begin{array}{l}\text { Aged } 0-24 \text { y, 1977-85: } \\
\text { John O'Gaunt, Lancaster, Lancashire } \\
\text { St Mary's, South Ribble, Lancashire } \\
\text { Burnden, Bolton, Greater Manchester } \\
\text { Beswick, Manchester, Greater Manchester } \\
\text { Caton, Lancaster, Lancashire }\end{array}$ & $\begin{array}{l}2347 \\
1755 \\
5138 \\
3492 \\
1228\end{array}$ & $\begin{array}{r}12 \\
10 \\
15 \\
11 \\
6\end{array}$ & $\begin{array}{l}4 \cdot 3 \\
4 \cdot 8 \\
2 \cdot 5 \\
2 \cdot 7 \\
4 \cdot 1\end{array}$ & $\begin{array}{l}.0000330 \\
.0000608 \\
.0015159 \\
.0034839 \\
.0037404\end{array}$ \\
\hline $\begin{array}{l}\text { Aged } 0-14 \text { y, 1977-85: } \\
\text { Yarm, Stockton on Tees, Cleveland } \\
\text { Seaton De Laval, Blyth Valley, Northumberland } \\
\text { Brownhill, Blackburn, Lancashire } \\
\text { Burnden, Bolton, Greater Manchester } \\
\text { Sandwith, Copeland, Cumbria }\end{array}$ & $\begin{array}{r}1606 \\
658 \\
1524 \\
2711 \\
744\end{array}$ & $\begin{array}{l}7 \\
4 \\
6 \\
8 \\
4\end{array}$ & $\begin{array}{l}4 \cdot 4 \\
6 \cdot 1 \\
4 \cdot 0 \\
3 \cdot 0 \\
5 \cdot 4\end{array}$ & $\begin{array}{l}.0013252 \\
.0045591 \\
.0046886 \\
.0065803 \\
.0069707\end{array}$ \\
\hline $\begin{array}{l}\text { Aged 15-24 y, 1977-85: } \\
\text { John O'Gaunt, Lancaster, Lancashire } \\
\text { St Mary's, South Ribble, Lancashire } \\
\text { Hulme, Manchester, Greater Manchester } \\
\text { Cramlington South East, Blyth Valley, Northumberland } \\
\text { Walton Le Dale South, South Ribble, Lancashire }\end{array}$ & $\begin{array}{r}1125 \\
717 \\
2747 \\
752 \\
1327\end{array}$ & $\begin{array}{r}9 \\
7 \\
13 \\
6 \\
8\end{array}$ & $\begin{array}{l}4 \cdot 8 \\
5 \cdot 8 \\
2 \cdot 8 \\
4 \cdot 8 \\
3 \cdot 6\end{array}$ & $\begin{array}{l}.0001507 \\
.0002481 \\
.0009568 \\
.0018822 \\
.0020690\end{array}$ \\
\hline
\end{tabular}

chester Regional Hospital Boards and the present Northern and North Western Regional Health Authorities plus the Southport and South Sefton districts of the Mersey region (fig 1). The local authority administrative counties included in the study area were Greater Manchester, Tyne and Wear, Cleveland, Cumbria, Durham, Lancashire, and Northumberland. The first three are large metropolitan urban areas with predominantly heavy engineering and chemical industries while the latter four are largely rural. All patients whose 'usual place of residence' at the time of diagnosis was within this area were included. The definition of 'usual place of residence' used was that defined by the Office of Population Censuses and Surveys for regional cancer registries.

All cases were reviewed to confirm eligibility for the study. This included review of hospital notes and pathological material where this had not been previously seen. Checking of neighbouring health authorities' cancer registries was not carried out, so it is possible that some cases on the borders of the region may have been missed if they were incorrectly attributed. All cases registered by the end of 1987 were included in the analysis.

Cases were classified according to the morphology (M) and topography (T) codes of the International Classification of Diseases for Oncology (ICD-0), 1976. ${ }^{8}$

*Incidence rate ratio; $\mathrm{P}=$ population; $\mathrm{C}=$ cases 
The location of each case at the time of diagnosis was coded by allocating them an Ordnance Survey eight figure grid reference. For the early years of the Manchester Children's Tumour Registry this had already been done directly for a previous study. For the remainder it was achieved by giving each case a postcode and converting this to a grid reference using a computerised matching

Table III Poisson probability ranking: all cancers, 1971 census population data

\begin{tabular}{|c|c|c|c|c|}
\hline \multirow[b]{2}{*}{ Ward name } & \multicolumn{2}{|c|}{ Numbers } & \multicolumn{2}{|c|}{ Statistics } \\
\hline & $P$ & $C$ & Rate $^{*}$ & Probubility \\
\hline \multicolumn{5}{|l|}{ Aged 0-24 y, 1968-85: } \\
\hline Birch Green, West Lancashire, Lancashire & 16 & 4 & $118 \cdot 1$ & $\cdot 0000001$ \\
\hline Parkside, Blyth Valley, Northumberland & 184 & 6 & $15 \cdot 4$ & .0000035 \\
\hline St Mary's, South Ribble, Lancashire & 1305 & 11 & $4 \cdot 0$ & $\cdot 0001458$ \\
\hline Yarm, Stockton on Tees, Cleveland & 1182 & 10 & $4 \cdot 0$ & .0002789 \\
\hline Shaw, Oldham, Greater Manchester & 2174 & 14 & $3 \cdot 0$ & .0003134 \\
\hline \multicolumn{5}{|l|}{ Aged $0-14 y, 1968-85$} \\
\hline Parkside, Blyth Valley, Northumberland & 103 & 5 & $27 \cdot 8$ & $\cdot 0000014$ \\
\hline Birch Green, West Lancashire, Lancashire & 8 & 2 & $143 \cdot 0$ & $\cdot 0000970$ \\
\hline Yarm, Stockton on Tees, Cleveland & 807 & 8 & $5 \cdot 7$ & .0001125 \\
\hline Shaw, Oldham, Greater Manchester & 1381 & 10 & $4 \cdot 1$ & $\cdot 0002117$ \\
\hline Hemlington, Middlesbrough, Cleveland & 22 & 2 & $52 \cdot 0$ & .0007214 \\
\hline \multicolumn{5}{|l|}{ Aged 15-24 y, 1968-85: } \\
\hline Birch Green, West Lancashire, Lancashire & 8 & 2 & $77 \cdot 2$ & .0003294 \\
\hline St Mary's, South Ribble, Lancashire & 397 & 7 & $5 \cdot 4$ & .0003766 \\
\hline Hulme, Manchester, Greater Manchester & 1502 & 14 & $2 \cdot 9$ & .0005337 \\
\hline Longhorsley, Castle Morpeth, Northumberland & 123 & 4 & $10 \cdot 0$ & .0007626 \\
\hline Walton Le Dale South, South Ribble, Iancashire & 777 & 9 & $3 \cdot 6$ & .0011866 \\
\hline \multicolumn{5}{|l|}{ Aged 0-24 y, 1968-76: } \\
\hline Prudhoe South, Tynedale, Northumberland & 1617 & & $4 \cdot 8$ & $\cdot 0003417$ \\
\hline Hutton, Langbaurgh, Cleveland & 855 & 5 & $5 \cdot 7$ & .0021468 \\
\hline Ormesby, Langbaurgh, Cleveland & 1355 & 6 & $4 \cdot 3$ & $\cdot 0031711$ \\
\hline Slaley \& Hexamshire, Tynedale, Northumberland & 314 & 3 & $9 \cdot 3$ & $\cdot 0044470$ \\
\hline Central, Bolton, Greater Manchester & 6040 & 14 & $2 \cdot 2$ & .0049849 \\
\hline \multicolumn{5}{|l|}{ Aged $0-14$ y, 1968-76: } \\
\hline Prudhoe South Tynedale, Northumberland & 907 & 5 & $6 \cdot 0$ & $\cdot 0017182$ \\
\hline No 6, Sedgefield Durham & 924 & 5 & $5 \cdot 9$ & .0018614 \\
\hline Norwood, Sefton, Merseyside & 2682 & 8 & $3 \cdot 2$ & .0040087 \\
\hline Easterside, Middlesbrough, Cleveland & 2162 & 7 & $3 \cdot \overline{5}$ & .0044806 \\
\hline Ashton St Michael's, Tameside, Greater Manchester & 2250 & 7 & $3 \cdot 4$ & .0055307 \\
\hline \multicolumn{5}{|l|}{ Aged 15-24 y, 1968-76: } \\
\hline Prudhoe South, Tynedale, Northumberland & 710 & 5 & $4 \cdot 9$ & .0039496 \\
\hline Clayton Le Moors, Hyndburn, Lancashire & 766 & 5 & $4 \cdot 6$ & .0054093 \\
\hline Great Moor, Stockport, Greater Manchester & 1835 & 8 & $3 \cdot 0$ & .0057235 \\
\hline Central Bolton, Greater Manchester & 2323 & 9 & $2 \cdot 7$ & .0073331 \\
\hline Cheadle, Stockport, Greater Manchester & 1560 & 7 & $3 \cdot 1$ & .0081389 \\
\hline
\end{tabular}

Table IV Poisson probability ranking: acute lymphoblastic leukaemia, 1981 census population data

\begin{tabular}{|c|c|c|c|c|}
\hline \multirow[b]{2}{*}{ Ward name } & \multicolumn{2}{|c|}{ Numbers } & \multicolumn{2}{|c|}{ Statistics } \\
\hline & $\bar{P}$ & C & Rate $^{*}$ & Probability \\
\hline \multicolumn{5}{|l|}{ Aged $0-24 y, 1968-85$} \\
\hline Seascale, Copeland, Cumbria & 750 & 4 & $14 \cdot 0$ & .0002223 \\
\hline Broughton, South Lakeland, Cumbria & 773 & 3 & $10 \cdot 2$ & .0034311 \\
\hline Whittingham, Alnwick, Northumberland & 266 & 2 & $19 \cdot 7$ & .0048128 \\
\hline Egremont North, Copeland, Cumbria & 1941 & 4 & $5 \cdot 4$ & .0069789 \\
\hline Nol, Sedgefield, Durham & 2138 & 4 & $4 \cdot 9$ & .0096901 \\
\hline \multicolumn{5}{|l|}{ Aged $0-14 y, 1968-85:$} \\
\hline Seascale, Copeland, Cumbria & 411 & 4 & $17 \cdot 5$ & .0000953 \\
\hline Broughton, South Lakeland, Cumbria & 451 & 3 & $11 \cdot 9$ & .0021909 \\
\hline Whittingham, Alnwick, Northumberland & 143 & 2 & $25 \cdot 1$ & .0030085 \\
\hline Orrell, Sefton, Merseyside & 2716 & 6 & $4 \cdot 0$ & $\cdot 0046392$ \\
\hline No 1. Sedgefield, Durham & 1208 & 4 & $5 \cdot 9$ & .0050165 \\
\hline \multicolumn{5}{|l|}{ Aged 15-24 y, 1968-85: } \\
\hline No 5. Salford, Greater Manchester & 2104 & 3 & $9 \cdot 0$ & .0048437 \\
\hline Great Moor. Stockport, Greater Manchester & 2299 & 3 & $8 \cdot 2$ & .0061767 \\
\hline Derby, Bolton, Greater Manchester & 2612 & 3 & $7 \cdot 2$ & .0087338 \\
\hline No 6 . Salford, Greater Manchester & 2735 & 3 & 6.9 & .0098841 \\
\hline No 6. North Tyneside, Tyne and Wear (Percy) & 1129 & 2 & $11 \cdot 2$ & .0142637 \\
\hline \multicolumn{5}{|l|}{ Aged $0-24$ y, 1977-85: } \\
\hline Meols, Sefton, Merseyside & 3821 & 4 & $5 \cdot 9$ & .0051221 \\
\hline Gosforth Nol. Newcastle upon Tyne, Tyne and Wear & 3911 & 4 & $5 \cdot 8$ & .0055524 \\
\hline No 1. Sedgefield, Durham & 2138 & 3 & $7 \cdot 9$ & .0068348 \\
\hline Broughton, South Lakeland, Cumbria & 773 & 2 & $14 \cdot 6$ & .0085624 \\
\hline Newtown, Stockton on Tees, Cleveland & 2538 & 3 & $6 \cdot 7$ & .0108540 \\
\hline \multicolumn{5}{|l|}{ Aged $0-14$ y, 1977-85: } \\
\hline Gosforth No 1. Newcastle upon Tyne, Tyne and Wear & 2010 & 4 & $7 \cdot 8$ & $\cdot 0018870$ \\
\hline Meols, Sefton, Merseyside & 2300 & 4 & $6 \cdot 8$ & .0030536 \\
\hline No 1. Sedgefield, Durham & 1208 & 3 & $9 \cdot 8$ & .0038296 \\
\hline Broughton, South Lakeland, Cumbria & 451 & 2 & $17 \cdot 5$ & .0060789 \\
\hline No 8. North Tyneside, Tyne and Wear (Carville, Hadrian) & 1445 & 3 & $8 \cdot 2$ & .0062704 \\
\hline \multicolumn{5}{|l|}{ Aged 15-24 y, 1977-85: } \\
\hline No 5. Salford Greater Manchester & 2104 & 3 & & .0007288 \\
\hline No 6. Salford, Greater Manchester & 2735 & 3 & 13.5 & .0015412 \\
\hline Unsworth, Bury, Greater Manchester & 1576 & 2 & $15 \cdot 6$ & .0075036 \\
\hline Milfield, Berwick upon Tweed, Northumberland & 167 & 1 & $73 \cdot 8$ & .0134516 \\
\hline Longhorsley, Castle Morpeth, Northumberland & 169 & 1 & $73 \cdot 0$ & .0136116 \\
\hline
\end{tabular}

table supplied by the Post Office (1988 edition). Where there was no clear match, a grid reference was derived by direct inspection of a large scale map of the area. The grid references were then used to allocate each case to the appropriate census ward via a 'point in polygon' procedure.

REFERENCE POPULATION STATISTICS

The population data used were those derived from the 1971 and 1981 censuses. The data for small areas were obtained from the 1981 census using SASPAC, a software package which is made available to all universities for academic use. For the 1971 census, the data were obtained from a complete set of census tapes purchased by the Economic and Social Research Council's North East Regional Research Laboratory at the University of Newcastle upon Tyne. The age specific population data for the whole study area were identified for both census wards and enumeration districts. The latter is the smallest area for which aggregated population data are available and corresponds to the area covered by one census enumerator. The census wards and enumeration districts as defined for 1971 and 1981 are not geographically identical. Census tracts are areas which are of similar size to wards and designed to be geographically identical in both censuses. Although the mean population of census tracts and wards is similar, however, there is a much larger standard deviation for tracts. A single geographical unit therefore had to be defined for the present study and this was taken as the 1981 census ward rather than the tract. Ward population counts from the 1981 census were obtained directly from SASPAC. The 1971 census data were allocated to 1981 census wards by obtaining population counts for 1971 enumeration districts. The grid reference of the 1971 enumeration district was then used to allocate the population count to the appropriate 1981 census ward using a point in polygon procedure. The enumeration district data were then summated to produce the 1971 population counts within 1981 census ward boundaries. There were 1272 census wards in the study area at the 1981 census. The population aged under 25 years at the 1981 census ranged from 131 to 17547 per census ward, and for the 1971 census from 0 to 10625 . The total population aged $0-24$ years in the study region at the 1981 census was 2686983 , and at the 1971 census it was 2915058 .

\section{CANCER RANKING TABLES}

The Black report recommended that census wards should be ranked by relative incidence rate and Poisson probability values, and this has been carried out for all major cancer types using different population bases-that is, 1971 or 1981 census and different time periods, either the whole 18 years or the periods $1968-76$ and 1977--85. The data were also examined using the age categorisation 0-14 years, 15-24 years, or 0-24 years. As acute lymphoblastic leukaemia and non-Hodgkins lymphoma were the main focus of interest of the Black report, results are presented for these disease categories separately and combined. Also included in this report are 'all cancer' combined and 'all brain tumours', the latter being the largest disease category after acute lym- 
phoblastic leukaemia. 'All brain tumours' includes most intracranial tumours although some, for example intracranial germ cell malignancies-are coded elsewhere. The ICD- $0 \mathrm{M}$ codes included in the data presented here are acute lymphoblastic leukaemia: $9820-9822+9824+9850$; nonHodgkins lymphoma: 9590-9642 + 9690-

Table V Poisson probability ranking: acute lymphoblastic leukaemia 1971 census population data

\begin{tabular}{|c|c|c|c|c|}
\hline \multirow[b]{2}{*}{ Ward name } & \multicolumn{2}{|c|}{ Numbers } & \multicolumn{2}{|c|}{ Statistics } \\
\hline & $P$ & $C$ & Rate* $^{*}$ & Probability \\
\hline $\begin{array}{l}\text { Aged 0-24 y, 1968-85: } \\
\text { Seascale, Copeland, Cumbria } \\
\text { Shaw, Oldham, Greater Manchester } \\
\text { Egremont North, Copeland, Cumbria } \\
\text { Broughton, South Lakeland, Cumbria } \\
\text { Whittingham, Alnwick, Northumberland }\end{array}$ & $\begin{array}{r}860 \\
2174 \\
1492 \\
820 \\
292\end{array}$ & $\begin{array}{l}4 \\
5 \\
4 \\
3 \\
2\end{array}$ & $\begin{array}{r}13.2 \\
6.5 \\
7.6 \\
10.4 \\
19.5\end{array}$ & $\begin{array}{l}.0002739 \\
.0011574 \\
.0020823 \\
.0032232 \\
.0049237\end{array}$ \\
\hline $\begin{array}{l}\text { Aged 0-14 y, 1968-85: } \\
\text { Seascale, Copeland, Cumbria } \\
\text { Shaw, Oldham, Greater Manchester } \\
\text { Broughton, South Lakeland, Cumbria } \\
\text { Whittingham, Alnwick, Northumberland } \\
\text { Birch Green, West Lancashire, Lancashire }\end{array}$ & $\begin{array}{r}605 \\
1381 \\
525 \\
182 \\
8\end{array}$ & $\begin{array}{l}4 \\
5 \\
3 \\
2 \\
1\end{array}$ & $\begin{array}{r}14 \cdot 3 \\
7 \cdot 8 \\
12 \cdot 4 \\
23 \cdot 8 \\
270 \cdot 4\end{array}$ & $\begin{array}{l}.0002041 \\
.0005215 \\
.0019888 \\
.0033475 \\
.0036917\end{array}$ \\
\hline $\begin{array}{l}\text { Aged 15-24 y, 1968-85: } \\
\text { No 5, Salford, Greater Manchester } \\
\text { Great Moor, Stockport, Greater Manchester } \\
\text { Derby, Bolton, Greater Manchester } \\
\text { Castle, Tynedale, Northumberland } \\
\text { Newton, Stockton on Tees, Cleveland }\end{array}$ & $\begin{array}{r}1647 \\
1835 \\
2255 \\
100 \\
1222\end{array}$ & $\begin{array}{l}3 \\
3 \\
3 \\
1 \\
2\end{array}$ & $\begin{array}{r}10 \cdot 6 \\
9.5 \\
7 \cdot 8 \\
58 \cdot 4 \\
9.6\end{array}$ & $\begin{array}{l}.0030320 \\
.0040947 \\
.0072069 \\
.0169808 \\
.0190720\end{array}$ \\
\hline $\begin{array}{l}\text { Aged 0-24 y, 1968-76: } \\
\text { Seascale, Copeland, Cumbria } \\
\text { Whittingham, Alnwick, Northumberland } \\
\text { Pendleside, Pendle, Lancashire } \\
\text { Egremont, North, Copeland, Cumbria } \\
\text { Greatmoor. Stockport, Greater Manchester }\end{array}$ & $\begin{array}{r}860 \\
292 \\
393 \\
1492 \\
5261\end{array}$ & $\begin{array}{l}3 \\
2 \\
2 \\
3 \\
5\end{array}$ & $\begin{array}{r}18 \cdot 5 \\
36 \cdot 4 \\
27 \cdot 0 \\
10 \cdot 7 \\
5 \cdot 0\end{array}$ & $\begin{array}{l}.0006275 \\
.0014578 \\
.0026076 \\
.0029996 \\
.0035210\end{array}$ \\
\hline $\begin{array}{l}\text { Aged 0-14 y, 1968-76: } \\
\text { Seascale, Copeland, Cumbria } \\
\text { Whittingham, Alnwick, Northumberland } \\
\text { Pendleside, Pendle, Lancashire } \\
\text { Shaw, Oldham, Greater Manchester } \\
\text { No 14. Salford, Greater Manchester }\end{array}$ & $\begin{array}{r}605 \\
182 \\
257 \\
1381 \\
2970\end{array}$ & $\begin{array}{l}3 \\
2 \\
2 \\
3 \\
4\end{array}$ & $\begin{array}{r}19 \cdot 7 \\
43 \cdot 7 \\
30 \cdot 9 \\
8 \cdot 6 \\
5 \cdot 4\end{array}$ & $\begin{array}{l}.0005242 \\
.0010164 \\
.0020015 \\
.0053960 \\
.0071948\end{array}$ \\
\hline $\begin{array}{l}\text { Aged 15-24 y, 1968-76: } \\
\text { Great Moor, Stockport, Greater Manchester } \\
\text { Blundell Sands, Sefton, Merseyside } \\
\text { Castle, Tynedale, Northumberland } \\
\text { Hedgeley, Alnwick, Northumberland } \\
\text { Miles Platting, Manchester, Greater Manchester }\end{array}$ & $\begin{array}{r}1835 \\
1499 \\
100 \\
127 \\
2051\end{array}$ & $\begin{array}{l}3 \\
2 \\
1 \\
1 \\
2\end{array}$ & $\begin{array}{r}19.5 \\
15.9 \\
119.4 \\
94.0 \\
11.6\end{array}$ & $\begin{array}{l}.0005397 \\
.0072544 \\
.0083422 \\
.0105826 \\
.0131737\end{array}$ \\
\hline
\end{tabular}

*Incidence rate ratio

Table VI Poisson probability ranking: non-Hodgkins lymphoma, 1981 census population data

\begin{tabular}{|c|c|c|c|c|}
\hline \multirow[b]{2}{*}{ Ward name } & \multicolumn{2}{|c|}{ Numbers } & \multicolumn{2}{|c|}{ Statistics } \\
\hline & $P$ & $C$ & Rate $^{*}$ & Probability \\
\hline $\begin{array}{l}\text { Aged 0-24 y, 1968-85: } \\
\text { Besses, Bury, Greater Manchester } \\
\text { Kendal Fell, South Lakeland, Cumbria } \\
\text { Seascale, Copeland, Cumbria } \\
\text { Penrith South, Eden, Cumbria } \\
\text { No 23. Sunderland, Tyne and Wear (Houghton No 2) }\end{array}$ & $\begin{array}{r}3869 \\
526 \\
750 \\
783 \\
3488\end{array}$ & $\begin{array}{l}4 \\
2 \\
2 \\
2 \\
3\end{array}$ & $\begin{array}{r}8 \cdot 3 \\
30 \cdot 5 \\
21 \cdot 4 \\
20 \cdot 5 \\
6.9\end{array}$ & $\begin{array}{l}.0015385 \\
.0020586 \\
.0041085 \\
.0044659 \\
.0099277\end{array}$ \\
\hline $\begin{array}{l}\text { Aged 0-14 y, 1968-85: } \\
\text { Kendall Fell, South Lakeland, Cumbria } \\
\text { Seascale, Copeland, Cumbria } \\
\text { No 23. Sunderland, Tyne and Wear (Houghton No 2) } \\
\text { Davenport, Stockport, Greater Manchester } \\
\text { Fairfield, Stockton on Tees, Cleveland }\end{array}$ & $\begin{array}{r}267 \\
411 \\
1944 \\
2374 \\
976\end{array}$ & $\begin{array}{l}2 \\
2 \\
3 \\
3 \\
2\end{array}$ & $\begin{array}{l}65.4 \\
42.5 \\
13.5 \\
11.0 \\
17.9\end{array}$ & $\begin{array}{r}.0004582 \\
.0010739 \\
.0015584 \\
.0027365 \\
.0058019\end{array}$ \\
\hline $\begin{array}{l}\text { Aged 15-24 y, 1968-85: } \\
\text { Penrith South, Eden, Cumbria } \\
\text { Derby, West Lancashire, Lancashire } \\
\text { Barclay, Burnley, Lancashire } \\
\text { Beechwood, Middlesbrough, Cleveland } \\
\text { Grove Hill, Middlesbrough, Cleveland }\end{array}$ & $\begin{array}{r}347 \\
894 \\
922 \\
982 \\
1044\end{array}$ & $\begin{array}{l}2 \\
2 \\
2 \\
2 \\
2\end{array}$ & $\begin{array}{l}35.9 \\
13.9 \\
13.5 \\
12.7 \\
11.9\end{array}$ & $\begin{array}{l}.0014938 \\
.0093567 \\
.0099226 \\
.0111849 \\
.0125594\end{array}$ \\
\hline $\begin{array}{l}\text { Aged } 0-24 \text { y, 1977-85: } \\
\text { Kendall Fell, South Lakeland, Cumbria } \\
\text { Seascale, Copeland, Cumbria } \\
\text { Grove Hill, Middlesbrough, Cleveland } \\
\text { Teesville, Langbaurgh, Cleveland } \\
\text { No 2. Salford, Greater Manchester }\end{array}$ & $\begin{array}{r}526 \\
750 \\
2294 \\
2672 \\
3265\end{array}$ & $\begin{array}{l}2 \\
2 \\
2 \\
2 \\
2\end{array}$ & $\begin{array}{r}61 \cdot 2 \\
42 \cdot 9 \\
14 \cdot 0 \\
12 \cdot 0 \\
9 \cdot 9\end{array}$ & $\begin{array}{r}0005229 \\
.0010532 \\
.0092476 \\
.0123538 \\
.0180048\end{array}$ \\
\hline $\begin{array}{l}\text { Aged 0-14 y, 1977-85: } \\
\text { Kendall Fell, South Lakeland, Cumbria } \\
\text { Seascale, Copeland, Cumbria } \\
\text { Teesville, Langbaurgh, Cleveland } \\
\text { Middleton Central, Rochdale, Greater Manchester } \\
\text { Arkholme, Lancaster, Lancashire }\end{array}$ & $\begin{array}{r}267 \\
411 \\
1400 \\
2432 \\
301\end{array}$ & $\begin{array}{l}2 \\
2 \\
2 \\
2 \\
1\end{array}$ & $\begin{array}{r}137.9 \\
89 \cdot 6 \\
26.3 \\
15 \cdot 1 \\
61.2\end{array}$ & $\begin{array}{l}.0001042 \\
.0002456 \\
.0027496 \\
.0079956 \\
.0162187\end{array}$ \\
\hline $\begin{array}{l}\text { Aged 15-24 y, 1977-85: } \\
\text { Grove Hill, Middlesbrough, Cleveland } \\
\text { No 3. Gateshead, Tyne and Wear, Claxton } \\
\text { Walton Le Dale South, South Ribble, Lancashire } \\
\text { Dunkinfield, Tameside, Greater Manchester } \\
\text { Bredbury, Stockport, Greater Manchester }\end{array}$ & $\begin{array}{l}1044 \\
1212 \\
1327 \\
1686 \\
1880\end{array}$ & $\begin{array}{l}2 \\
2 \\
2 \\
2 \\
2\end{array}$ & $\begin{array}{l}22 \cdot 2 \\
19 \cdot 1 \\
17 \cdot 5 \\
13 \cdot 8 \\
12 \cdot 3\end{array}$ & $\begin{array}{l}.0038206 \\
.0051000 \\
.0060738 \\
.0096065 \\
.0118136\end{array}$ \\
\hline
\end{tabular}

9698; all brain tumours: $9350-9481$; and all cancers: 8000-9999.

The cancer incidence in each ward was calculated by conventional methods as the standardised incidence rate and standarised rate ratio relative to the whole regional rate-that is, using the whole study area.

Ethical permission for the study was received from the appropriate authorities in the study areas.

\section{Results}

A total of 6686 cases of cancer in 0-24 year olds were eligible for the analysis. The tumour types and distribution by age and registry of origin are shown in table I. The cases from the two Mersey districts are included in the Manchester registry figures. The standardised incidence rate and standardised rate ratio for all cancers, acute lymphoblastic leukaemia, non-Hodgkin's lymphoma, and all brain tumours showed no significant variation between the seven administrative counties included in the study area. The top five ranked census wards for the analyses described above are shown in tables II-XI. As the census ward of Seascale has been the major focus of previous attention, the cases occurring there are listed in table XII along with the relevant population data.

\section{Discussion}

The apparent excess of leukaemia and lymphoma in young people in the village of Seascale was first highlighted by Yorkshire Television, and has subsequently been confirmed by others. ${ }^{9} 10$ The proximity to the large nuclear fuel reprocessing plant at Sellafield has led to an enormous focus of attention on the area and attempts to link the apparent increased risk of lymphoid malignancy to radiation discharges or some other factor associated with the plant. The finding of increases in incidence of leukaemia around other nuclear establishments in the $\mathrm{UK}^{11} 12$ has heightened speculation about a causal relation. The purpose of the present study was not to explore this possibility, which has been considered by others, ${ }^{4}$ but to determine whether the incidences of acute lymphoblastic leukaemia and non-Hodgkin's lymphoma in Seascale remain unusual when put into a wider context. The wider context taken for this study when compared with that presented to the Black committee, has been both geographical, to include the north western and part of the Mersey regions as well as the northern health region; temporal, extending the time period to 1985; has increased the age of cases considered to 24 years; and has considered all cancers as well as subtypes. Many reports of the excess of leukaemia around Sellafield have included cases occurring in both the 1950s and 1960s. There were no comprehensive cancer registrations at either a national or local level for this period and it is only by the most intensive scrutiny of a relatively small area that the cases in west Cumbria have been identified. Without similar intensive study to ascertain cases in the rest of the study region it would be scientifically unsound to extend the period of the present study retrospectively to before 1968. Although comprehensive data do exist from 1953 for the north

*Incidence rate ratio 
west region, prospective data collection did not start in the northern region until 1968. Identical case ascertainment methods have been used for the whole study region since 1968 , and no additional eligible cases not already recorded in either the Newcastle or Manchester registries have been identified by the investigations of others.

Table VII Poisson probability ranking: non-Hodgkins lymphoma 1971 census population data

\begin{tabular}{|c|c|c|c|c|}
\hline \multirow[b]{2}{*}{ Ward name } & \multicolumn{2}{|c|}{ Numbers } & \multicolumn{2}{|c|}{ Statistics } \\
\hline & $\bar{P}$ & $C$ & Rate $^{\star}$ & Probability \\
\hline $\begin{array}{l}\text { Aged } 0-24 \text { y, 1968-85: } \\
\text { Besses, Bury, Greater Manchester } \\
\text { Seascale, Copeland, Cumbria } \\
\text { Penrith South, Eden, Cumbria } \\
\text { Kendal Fell, South Lakeland, Cumbria } \\
\text { No 23. Sunderland, Tyne and Wear (Houghton No 2) }\end{array}$ & $\begin{array}{r}4259 \\
860 \\
882 \\
959 \\
3780\end{array}$ & $\begin{array}{l}4 \\
2 \\
2 \\
2 \\
3\end{array}$ & $\begin{array}{r}8 \cdot 2 \\
20 \cdot 2 \\
19 \cdot 7 \\
18 \cdot 1 \\
6 \cdot 9\end{array}$ & $\begin{array}{l}.0016218 \\
.0045737 \\
.0048026 \\
.0056447 \\
.0098991\end{array}$ \\
\hline $\begin{array}{l}\text { Aged 0-14 y, 1968-85: } \\
\text { Kendal Fell, South Lakeland, Cumbria } \\
\text { No 23. Sunderland, Tyne and Wear (Hougton No 2) } \\
\text { Seascale, Copeland, Cumbria } \\
\text { Davenport, Stockport, Greater Manchester } \\
\text { Fairfield, Stockton on Tees, Cleveland }\end{array}$ & $\begin{array}{r}530 \\
2358 \\
605 \\
2651 \\
1385\end{array}$ & $\begin{array}{l}2 \\
3 \\
2 \\
3 \\
2\end{array}$ & $\begin{array}{l}39 \cdot 7 \\
13 \cdot 4 \\
34 \cdot 8 \\
11 \cdot 9 \\
15 \cdot 2\end{array}$ & $\begin{array}{l}.0012276 \\
.0015887 \\
.0015921 \\
.0022114 \\
.0079444\end{array}$ \\
\hline $\begin{array}{l}\text { Aged 15-24 y, 1968-85: } \\
\text { Penrith South Eden, Cumbria } \\
\text { Barclay, Burnley, Lancashire } \\
\text { Walton le Dale South, South Ribble, Lancashire } \\
\text { Derby, West Lancashire, Lancashire } \\
\text { Beechwood, Middlesbrough, Cleveland }\end{array}$ & $\begin{array}{l}281 \\
706 \\
777 \\
833 \\
885\end{array}$ & $\begin{array}{l}2 \\
2 \\
2 \\
2 \\
2\end{array}$ & $\begin{array}{l}41 \cdot 1 \\
16 \cdot 4 \\
14 \cdot 9 \\
13 \cdot 9 \\
13 \cdot 1\end{array}$ & $\begin{array}{l}.0011457 \\
.0068882 \\
.0082760 \\
.0094513 \\
.0106051\end{array}$ \\
\hline $\begin{array}{l}\text { Aged 0-24 y, 1968-85: } \\
\text { Besses, Bury, Greater Manchester } \\
\text { Faifield, Stockton on Tees, Cleveland } \\
\text { No 4. Salford, Greater Manchester } \\
\text { Middleton East, Rochdale, Greater Manchester } \\
\text { Newcomen, Langbaurgh, Cleveland }\end{array}$ & $\begin{array}{l}4259 \\
2112 \\
2913 \\
2982 \\
3004\end{array}$ & $\begin{array}{l}3 \\
2 \\
2 \\
2 \\
2\end{array}$ & $\begin{array}{l}12 \cdot 2 \\
16 \cdot 4 \\
11 \cdot 9 \\
11 \cdot 6 \\
11 \cdot 6\end{array}$ & $\begin{array}{l}.0020526 \\
.0068331 \\
.0126099 \\
.0131798 \\
.0133639\end{array}$ \\
\hline $\begin{array}{l}\text { Aged 0-14 y, 1968-76: } \\
\text { Fairfield, Stockton on Tees, Cleveland } \\
\text { St Matthew's, Preston, Lancashire } \\
\text { No 23. Sunderland, Tyne and Wear (Houghton No 2) } \\
\text { Davenport, Stockport, Greater Manchester } \\
\text { Slaley \& Hexhamshire, Tynedale, Northumerland }\end{array}$ & $\begin{array}{r}1385 \\
2188 \\
2358 \\
2651 \\
194\end{array}$ & $\begin{array}{l}2 \\
2 \\
2 \\
2 \\
1\end{array}$ & $\begin{array}{r}28 \cdot 9 \\
18 \cdot 3 \\
17 \cdot 0 \\
15 \cdot 1 \\
103 \cdot 1\end{array}$ & $\begin{array}{l}\cdot 0022882 \\
\cdot 0055610 \\
\cdot 0064226 \\
\cdot 0080398 \\
\cdot 0096494\end{array}$ \\
\hline $\begin{array}{l}\text { Aged 15-24 y, 1968-76: } \\
\text { Beechwood, Middlesbrough, Cleveland } \\
\text { Newcomen, Langbaurgh, Cleveland } \\
\text { No 4. Salford, Greater Manchester } \\
\text { Redvales, Bury, Greater Manchester } \\
\text { Edgeley, Stockport, Greater Manchester }\end{array}$ & $\begin{array}{r}885 \\
979 \\
1099 \\
1712 \\
2231\end{array}$ & $\begin{array}{l}2 \\
2 \\
2 \\
2 \\
2\end{array}$ & $\begin{array}{l}28 \cdot 2 \\
25 \cdot 5 \\
22 \cdot 7 \\
14 \cdot 6 \\
11 \cdot 2\end{array}$ & $\begin{array}{l}.0023939 \\
.0029149 \\
.0036500 \\
.0085750 \\
.0141696\end{array}$ \\
\hline
\end{tabular}

${ }^{\star}$ Incidence rate ratio

Table VIII Poisson probability ranking: all brain tumours 1981 census population data

\begin{tabular}{|c|c|c|c|c|}
\hline \multirow[b]{2}{*}{ Ward name } & \multicolumn{2}{|c|}{ Numbers } & \multicolumn{2}{|c|}{ Statistics } \\
\hline & $\bar{P}$ & $C$ & Rate $^{\star}$ & Probability \\
\hline $\begin{array}{l}\text { Aged } 0-24 \text { y, 1968-85: } \\
\text { Ashton St Michael's, Tameside, Greater Manchester } \\
\text { No 9, North Tyneside, Tyne and Wear Howden } \\
\text { Alexandra, Oldham, Greater Manchester } \\
\text { Northgate North, Darlington, Durham } \\
\text { Kendall Fell, South Lakeland, Cumbria }\end{array}$ & $\begin{array}{r}3889 \\
3095 \\
5334 \\
1386 \\
526\end{array}$ & $\begin{array}{l}7 \\
5 \\
6 \\
3 \\
2\end{array}$ & $\begin{array}{r}5 \cdot 8 \\
5 \cdot 2 \\
3 \cdot 6 \\
7 \cdot 0 \\
12 \cdot 3\end{array}$ & $\begin{array}{l}.0002564 \\
.0030602 \\
.0070020 \\
.0095821 \\
.0119076\end{array}$ \\
\hline $\begin{array}{l}\text { Aged 0-14 y, 1968-85: } \\
\text { Ashton St Michael's, Tameside, Greater Manchester } \\
\text { Northgate North, Darlington, Durham } \\
\text { Kendall Fell, South Lakeland, Cumbria } \\
\text { Reedley, Pendle, Lancashire } \\
\text { No 1. Salford, Greater Manchester }\end{array}$ & $\begin{array}{r}2179 \\
723 \\
267 \\
935 \\
2064\end{array}$ & $\begin{array}{l}7 \\
3 \\
2 \\
3 \\
4\end{array}$ & $\begin{array}{r}8 \cdot 6 \\
11 \cdot 1 \\
20 \cdot 0 \\
8 \cdot 6 \\
5 \cdot 2\end{array}$ & $\begin{array}{l}.0000235 \\
.0027018 \\
.0046752 \\
.0055109 \\
.0080728\end{array}$ \\
\hline $\begin{array}{l}\text { Aged 15-24 y, 1968-85: } \\
\text { No 9. North Tyneside, Tyne and Wear (Howdon) } \\
\text { Pharos, Wyre, Lancashire } \\
\text { Norden, Hyndburn, Lancashire } \\
\text { No 14. Gateshead, Tyne and Wear } \\
\text { (Felling Central \& North) }\end{array}$ & $\begin{array}{r}1451 \\
497 \\
497 \\
1572\end{array}$ & $\begin{array}{l}4 \\
2 \\
2 \\
3\end{array}$ & $\begin{array}{r}10 \cdot 9 \\
15.9 \\
15.9 \\
7.5\end{array}$ & $\begin{array}{l}.0005633 \\
.0072606 \\
.0072606 \\
.0077857\end{array}$ \\
\hline $\begin{array}{l}\text { Carleton, Wyre, Lancashire } \\
\text { Aged } 0-24 \text { y, 1977-85: }\end{array}$ & 546 & 2 & $14 \cdot 5$ & $\cdot 0086916$ \\
\hline $\begin{array}{l}\text { Cribden, Rossendale, Lancashire } \\
\text { Overton, Hyndburn, Lancashire } \\
\text { No 7. Salford, Greater Manchester } \\
\text { North Lodge, Chester le Street, Durham } \\
\text { Brownhill, Blackburn, Lancashire }\end{array}$ & $\begin{array}{r}2007 \\
2194 \\
2410 \\
801 \\
2567\end{array}$ & $\begin{array}{l}3 \\
3 \\
3 \\
2 \\
3\end{array}$ & $\begin{array}{r}9 \cdot 6 \\
8 \cdot 8 \\
8 \cdot 0 \\
16 \cdot 1 \\
7 \cdot 5\end{array}$ & $\begin{array}{l}.0039944 \\
.0051077 \\
.0066047 \\
.0071150 \\
.0078397\end{array}$ \\
\hline $\begin{array}{l}\text { Aged } 0-14 \text { y, 1977-85: } \\
\text { Brownhill, Blackburn, Lancashire } \\
\text { North Reddish, Stockport, Greater Manchester } \\
\text { Wampool, Allerdale, Cumbria } \\
\text { No 1. Salford, Greater Manchester } \\
\text { Ince, Wigan, Greater Manchester }\end{array}$ & $\begin{array}{r}1524 \\
3479 \\
604 \\
2064 \\
2141\end{array}$ & $\begin{array}{l}3 \\
4 \\
2 \\
3 \\
3\end{array}$ & $\begin{array}{r}11 \cdot 2 \\
6.5 \\
18 \cdot 8 \\
8 \cdot 3 \\
8 \cdot 0\end{array}$ & $\begin{array}{l}.0026364 \\
.0036118 \\
.0052691 \\
.0061055 \\
.0067470\end{array}$ \\
\hline $\begin{array}{l}\text { Aged 15-24 y, 1977-85: } \\
\text { Newburn No } 1 \text { (Denton), Newcastle upon Tyne } \\
\text { Pharos, Wyre, Lancashire } \\
\text { Carleton, Wyre, Lancashire } \\
\text { Normanby, Langbaurgh, Cleveland } \\
\text { No 4. Sedgefield, Durham }\end{array}$ & $\begin{array}{r}1721 \\
497 \\
546 \\
699 \\
877\end{array}$ & $\begin{array}{l}3 \\
2 \\
2 \\
2 \\
2\end{array}$ & $\begin{array}{l}12 \cdot 3 \\
28 \cdot 4 \\
25 \cdot 9 \\
20 \cdot 2 \\
16 \cdot 1\end{array}$ & $\begin{array}{l}.0020068 \\
.0023594 \\
.0028346 \\
.0045796 \\
.0070901\end{array}$ \\
\hline
\end{tabular}

*Incidence rate ratio
Table XII shows that the occurrence of acute lymphoblastic leukaemia and non-Hodgkin's lymphoma in young people in Seascale is not evenly distributed across time. Most cases of acute lymphoblastic leukaemia are in the first period of the study (1968-76) and most of the nonHodgkin's lymphoma cases are in the second (1977-85). The age distribution is also uneven. The position of Seascale in the cancer ranking tables will clearly be dependent on both the time period and age range used. This study has shown that Seascale remains the ward most highly ranked by Poisson probability for acute lymphoblastic leukaemia incidence but only for either the whole time period of 1968-85 or the earlier period of 1968-76. Seascale, for obvious reasons (only one case) does not figure among the top ranked wards if the later time period of 1977-85 or only the older age group of 15-24 year olds are considered. For non-Hodgkin's lymphoma Seascale is highly, but not highest, ranked for the time periods and age categories relevant to the occurrence of the cases. Combining acute lymphoblastic leukaemia and non-Hodgkin's lymphoma, the results in Seascale become even more extreme for some of the analyses.

The justification for combining acute lymphoblastic leukaemia and non-Hodgkin's lymphoma is that both are lymphoid malignancies and that in the past there may have been difficulty in distinguishing the two. They may well both originate from a common stem cell and may share common aetiological factors. ${ }^{13}$

In the wider context of other disease types, Seascale is not the most highly ranked and does not have an excess of other cancers. By virtue of the cases of acute lymphoblastic leukaemia and non-Hodgkin's lymphoma, it does appear among the most highly ranked for all cancers, but for only one of the analyses was it top ranked. The absolute Poisson probabilities achieved by other disease categories can also be considered. The most extreme Poisson probability for any of the individual disease categories was that seen for all brain tumors in Ashton St Michael's, $(p=0.000009)$ an urban ward in Tameside, Greater Manchester. That of $p=0.000001$ for Birch Green in table III is almost certainly artefactual. It can therefore be seen that while Seascale remains unusual for acute lymphoblastic leukaemia when particular time periods and age categories are used, it is at least matched by other wards for other diseases and time periods. It is recognised, however, that it is difficult to attatch real significance to the absolute Poisson probability figure because of the problem of multiple significance testing. For a study such as this, the rank position of a ward is probably more important than the absolute Poisson probability value.

It can be concluded therefore that the incidences of acute lymphoblastic leukaemia and non-Hodgkin's lymphoma in Seascale ward remain unusual when put into a wider context. This finding is, however, restricted to an earlier time period and younger age range. There has only been one case of acute lymphoblastic leukaemia in Seascale in the past 20 years. If the time period 1972-89 were considered, the expected number of cases from $0-24$ years would be 0.3 and the observed has been 1 . 
This report has concentrated on the ward of Seascale as has much of the other research in the wake of the Black report. The original allegations in the Yorkshire Television programme were, however, related to a larger geographical area of west Cumbria. The study presented here does not give any suggestion of an increase in the number of

Table IX Poisson probability ranking: all brain tumours 1971 census population data

\begin{tabular}{|c|c|c|c|c|}
\hline \multirow[b]{2}{*}{ Ward name } & \multicolumn{2}{|c|}{ Numbers } & \multicolumn{2}{|c|}{ Statistics } \\
\hline & $P$ & $C$ & Rate* & Probability \\
\hline $\begin{array}{l}\text { Aged 0-24 y, 1968-85: } \\
\text { Ashton St Michael's, Tameside, Greater Manchester } \\
\text { Carleton, Wyre, Lancashire } \\
\text { No 9. North Tyneside, Tyne and Wear (Howdon) } \\
\text { Birch Green, West Lancashire, Lancashire } \\
\text { Alexandra, Oldham, Greater Manchester }\end{array}$ & $\begin{array}{r}3746 \\
963 \\
3421 \\
16 \\
5625\end{array}$ & $\begin{array}{l}7 \\
3 \\
5 \\
1 \\
6\end{array}$ & $\begin{array}{r}6.5 \\
10.9 \\
5 \cdot 1 \\
219.0 \\
3.7\end{array}$ & $\begin{array}{l}\cdot 0001252 \\
\cdot 0028200 \\
\cdot 0033108 \\
\cdot 0045562 \\
\cdot 0061371\end{array}$ \\
\hline $\begin{array}{l}\text { Aged 0-14 y, 1968-85: } \\
\text { Ashton St Michael's, Tameside, Greater Manchester } \\
\text { Birch Green, West Lancashire, Lancashire } \\
\text { Northgate North, Darlington, Durham } \\
\text { Reedley, Pendle, Lancashire } \\
\text { Healey, Rochdale, Greater Manchester }\end{array}$ & $\begin{array}{r}2250 \\
8 \\
850 \\
926 \\
2250\end{array}$ & $\begin{array}{l}7 \\
1 \\
3 \\
3 \\
4\end{array}$ & $\begin{array}{r}10 \cdot 0 \\
402 \cdot 3 \\
11 \cdot 4 \\
10 \cdot 4 \\
5 \cdot 7\end{array}$ & $\begin{array}{l}.0000088 \\
.0024829 \\
.0025228 \\
.0032053 \\
.0057304\end{array}$ \\
\hline $\begin{array}{l}\text { Aged 15-24 y, 1968-85: } \\
\text { No 9. North Tyneside, Tyne and Wear (Howden) } \\
\text { No 4. Sedgefield, Durham } \\
\text { Carleton, Wyre, Lancashire } \\
\text { Norden, Hyndburn, Lancashire } \\
\text { No 14, Gateshead, Tyne and Wear } \\
\text { (Felling Central \& North) }\end{array}$ & $\begin{array}{r}1498 \\
185 \\
328 \\
421 \\
1387\end{array}$ & $\begin{array}{l}4 \\
2 \\
2 \\
2 \\
3\end{array}$ & $\begin{array}{r}9 \cdot 8 \\
39 \cdot 6 \\
22 \cdot 4 \\
17 \cdot 4 \\
7 \cdot 9\end{array}$ & $\begin{array}{l}.0008390 \\
.0012308 \\
.0037702 \\
.0061080 \\
.0068112\end{array}$ \\
\hline $\begin{array}{l}\text { Aged 0-24 y, 1968--76: } \\
\text { Ashton St Michael's, Tameside, Greater Manchester } \\
\text { No 4. Wear Valley, Durham } \\
\text { Spotland, Rochdale, Greater Manchester } \\
\text { Kendal Fell, South Lakeland, Cumbria } \\
\text { No 5. North Tyneside, Tyne and Wear (Linskill) }\end{array}$ & $\begin{array}{r}3746 \\
2340 \\
2678 \\
959 \\
3158\end{array}$ & $\begin{array}{l}5 \\
3 \\
3 \\
2 \\
3\end{array}$ & $\begin{array}{r}9 \cdot 4 \\
9 \cdot 0 \\
7 \cdot 9 \\
14 \cdot 6 \\
6 \cdot 7\end{array}$ & $\begin{array}{l}\cdot 0002312 \\
\cdot 0048096 \\
\cdot 0069584 \\
\cdot 0085135 \\
\cdot 0108526\end{array}$ \\
\hline $\begin{array}{l}\text { Aged 0-14 y, 1968-76: } \\
\text { Ashton St Michael's, Tameside, Greater Manchester } \\
\text { Spotland, Rochdale, Greater manchester } \\
\text { Kendal Fell, South Lakeland, Cumbria } \\
\text { Healey, Rochdale, Greater Manchester } \\
\text { Broadheath, Trafford, Greater Manchester }\end{array}$ & $\begin{array}{r}2250 \\
1676 \\
530 \\
2250 \\
2511\end{array}$ & $\begin{array}{l}5 \\
3 \\
2 \\
3 \\
3\end{array}$ & $\begin{array}{r}13 \cdot 5 \\
10 \cdot 9 \\
22 \cdot 9 \\
8 \cdot 1 \\
7 \cdot 3\end{array}$ & $\begin{array}{l}\cdot 0000427 \\
.0028498 \\
.0035914 \\
.0064309 \\
.0086607\end{array}$ \\
\hline $\begin{array}{l}\text { Aged 15-24 y, 1968-76: } \\
\text { No 14. Gateshead, Tyne and Wear } \\
\text { (Felling Central \& North) }\end{array}$ & 1387 & 3 & $18 \cdot 0$ & .0006798 \\
\hline $\begin{array}{l}\text { Norden, Hyndburn, Lancashire } \\
\text { Brookfield, Middlesbrough, Cleveland } \\
\text { No } 6 \text {. South Tyneside, Tyne and Wear (Horsley Hill) } \\
\text { No 9. North Tyneside, Tyne and Wear (Howden) }\end{array}$ & $\begin{array}{r}421 \\
818 \\
1085 \\
1498\end{array}$ & $\begin{array}{l}2 \\
2 \\
2 \\
2\end{array}$ & $\begin{array}{l}39 \cdot 6 \\
20 \cdot 4 \\
15 \cdot 4 \\
11 \cdot 1\end{array}$ & $\begin{array}{l}\cdot 0012354 \\
\cdot 0045190 \\
\cdot 0077840 \\
\cdot 0143614\end{array}$ \\
\hline
\end{tabular}

${ }^{\star}$ Incidence rate ratio

Table $X$ Poisson probability ranking: acute lymphoblastic leukaemia and non-Hodgkins lymphoma, 1981 census population data

\begin{tabular}{|c|c|c|c|c|}
\hline \multirow[b]{2}{*}{ Ward name } & \multicolumn{2}{|c|}{ Numbers } & \multicolumn{2}{|c|}{ Statistics } \\
\hline & $P$ & $C$ & Rate & Probability \\
\hline $\begin{array}{l}\text { Aged 0-24 y, 1968-85: } \\
\text { Seascale, Copeland, Cumbria } \\
\text { No 1. Sedgefield, Durham } \\
\text { John O'Gaunt, Lancaster, Lancashire } \\
\text { Broughton, South Lakeland, Cumbria } \\
\text { Whittingham, Alnwick, Northumberland }\end{array}$ & $\begin{array}{r}750 \\
2138 \\
2347 \\
773 \\
266\end{array}$ & $\begin{array}{l}6 \\
5 \\
5 \\
3 \\
2\end{array}$ & $\begin{array}{r}15 \cdot 8 \\
4 \cdot 6 \\
4 \cdot 2 \\
7 \cdot 7 \\
14 \cdot 9\end{array}$ & $\begin{array}{l}.0000030 \\
.0050656 \\
.0074138 \\
.0074504 \\
.0082777\end{array}$ \\
\hline $\begin{array}{l}\text { Aged 0-14 y, 1968-85: } \\
\text { Seascale, Copeland, Cumbria } \\
\text { No 1. Sedgefield, Durham } \\
\text { Broughton, South Lakeland, Cumbria } \\
\text { Whittingham, Alnwick, Northumberland } \\
\text { Fairfield, Stockton on Tees, Cleveland }\end{array}$ & $\begin{array}{r}411 \\
1208 \\
451 \\
143 \\
976\end{array}$ & $\begin{array}{l}6 \\
5 \\
3 \\
2 \\
4\end{array}$ & $\begin{array}{r}21 \cdot 7 \\
6 \cdot 2 \\
9 \cdot 9 \\
20 \cdot 8 \\
6 \cdot 1\end{array}$ & $\begin{array}{l}.0000005 \\
.0014992 \\
.0036956 \\
.0043260 \\
.0045785\end{array}$ \\
\hline $\begin{array}{l}\text { Aged 15-24 y, 1968-85: } \\
\text { Longhorsley, Castle Morpeth, Northumerland } \\
\text { Derby, Bolton, Greater Manchester } \\
\text { Grove Hill, Middlesbrough, Cleveland } \\
\text { Penrith South, Eden, Cumbria } \\
\text { No 4. Salford, Greater Manchester }\end{array}$ & $\begin{array}{r}169 \\
2612 \\
1044 \\
347 \\
1201\end{array}$ & $\begin{array}{l}2 \\
5 \\
3 \\
2 \\
3\end{array}$ & $\begin{array}{r}37 \cdot 2 \\
6 \cdot 0 \\
9 \cdot 0 \\
18 \cdot 1 \\
7 \cdot 8\end{array}$ & $\begin{array}{l}.0013963 \\
.0016686 \\
.0047785 \\
.0056700 \\
.0070120\end{array}$ \\
\hline $\begin{array}{l}\text { Aged 0-24 y, 1977-85: } \\
\text { Seascale, Copeland, Cumbria } \\
\text { Gosforth No 1. Newcastle upon Tyne, Tyne and Wear } \\
\text { Longhorsley, Castle Morpeth, Northumberland } \\
\text { Kendal Fell, South Lakeland, Cumbria } \\
\text { Meols, Sefton Merseyside }\end{array}$ & $\begin{array}{r}750 \\
3911 \\
346 \\
526 \\
3821\end{array}$ & $\begin{array}{l}3 \\
5 \\
2 \\
2 \\
4\end{array}$ & $\begin{array}{r}16 \cdot 7 \\
5 \cdot 3 \\
24 \cdot 2 \\
15 \cdot 9 \\
4 \cdot 4\end{array}$ & $\begin{array}{l}.0008427 \\
.0027685 \\
.0032443 \\
.0072876 \\
.0141806\end{array}$ \\
\hline $\begin{array}{l}\text { Aged } 0-14 \text { y, 1977-85: } \\
\text { Seascale, Copeland, Cumbria } \\
\text { Gosforth No 1, Newcastle upon Tyne, Tyne and Wear } \\
\text { Kendal Fell, South Lakeland, Cumbria } \\
\text { Heaton Moor, Stockport, Greater Manchester } \\
\text { Meols, Sefton, Merseyside }\end{array}$ & $\begin{array}{r}411 \\
2010 \\
267 \\
2098 \\
2300\end{array}$ & $\begin{array}{l}3 \\
5 \\
2 \\
4 \\
4\end{array}$ & $\begin{array}{r}23 \cdot 7 \\
8 \cdot 1 \\
24 \cdot 3 \\
6 \cdot 2 \\
5 \cdot 6\end{array}$ & $\begin{array}{l}.0003084 \\
.0004560 \\
.0032072 \\
.0043709 \\
.0060137\end{array}$ \\
\hline $\begin{array}{l}\text { Aged 15-24 y, 1977-85: } \\
\text { Longhorsley, Castle Morpeth, Northumberland } \\
\text { No 20. North Tyneside, Tyne and Wear (Camperdown) } \\
\text { No 5. Salford, Greater Manchester } \\
\text { Derby, Bolton, Greater Manchester } \\
\text { No 6. Salford, Greater Manchester }\end{array}$ & $\begin{array}{r}169 \\
2723 \\
2104 \\
2612 \\
2735\end{array}$ & $\begin{array}{l}2 \\
4 \\
3 \\
3 \\
3 \\
\end{array}$ & $\begin{array}{r}70 \cdot 7 \\
8 \cdot 8 \\
8 \cdot 5 \\
6 \cdot 9 \\
6 \cdot 6 \\
\end{array}$ & $\begin{array}{l}.0003926 \\
.0012518 \\
.0056018 \\
.0100688 \\
.0113863\end{array}$ \\
\hline
\end{tabular}

*Incidence rate ratio highly ranked wards in west Cumbria, apart from Seascale. The whole question of using arbitrary administrative boundaries, however, is one that has engendered considerable research activity over the past few years. Openshaw has devised a Geographical Analysis Machine ${ }^{14}$ using a search technique dependent on covering a study area with overlapping circles of various sizes, calculating the rate of disease occurrence in all of the circles and identifying those where the rate is unusual. When used on the same data set as that included in the present study the Geographical Analysis Machine identifies an excess in Seascale but also in other areas distant from Seascale where there seem to be similar or even greater excesses. ${ }^{14}$ Other methods developed include those of Besag and Newell, ${ }^{15}$ Bithell and Stone, ${ }^{16}$ and Cuzick and Edwards. ${ }^{17}$

The Black report's recommendation 4 included analysis by place of birth as well as by place of diagnosis. To comply with this an attempt was made to obtain the birth certificates for all of the cases who had cancer diagnosed before their 15th birthday. There is increasing evidence that events occurring around the time of conception, pregnancy, or birth may be important in the aetiology of acute lymphoblastic leukaemia ${ }^{13}$ and the suggestion was that using only the place of residence at diagnosis would dilute any possible early environmental factor. It was thought unlikely, however, that this would influence the analysis for the older cases. Birth certificates were therefore obtained for $69 \%$ of the $0-14$ year olds in the present study. Although almost $50 \%$ of cases had moved house between birth and diagnosis, most had moved only $5 \mathrm{~km}$ or less. The original intention had been to produce ranking tables based on place of birth. This would have been rendered uninterpretable, however, because the registration data included only patients who were diagnosed while living in the study area and would have excluded cases born in the area who moved to another part of the country and developed cancer while living there. The Seascale birth cohort study ${ }^{2}$ has shown that this does occur and the only solution is the national birth cohort study of acute lymphoblastic leukaemia and non-Hodgkin's lymphoma using the data held by the Childhood Cancer Research Group in Oxford.

An additional problem encountered in studies of this type is the imbalance between the accuracy of numerator and denominator data. While the cases can be located to a single point in time, the reference population data are only available at two time points, 10 years apart. Any particular case may therefore be allocated to a population which is up to five years out of date. The basic locational unit used in the present study was the enumeration district and more detailed data other than those obtained at the census are not available for such small areas. Inter-census Office of Population Censuses and Surveys estimates are available at a regional and district level, but are not available for smaller areas. It was felt inappropriate to use anything other than fixed, definitive populations and that attempts at extrapolation between the 1971 and 1981 populations for small areas would be fraught with inaccuracies. An average could be taken of the 1971 and 1981 populations for wards as defined in this study but there is no guarantee that this would be any more accurate. Any excess 
which survives the analysis using either the 1971 or 1981 data is probably of importance. The most extreme ranking of Birch Green in table III using the 1971 census data, but the whole time period for cancer occurrence with Birch Green's complete absence from the top ranked wards using the 1981 population indicates that large population changes have occurred and the extreme result is spurious.

It can be seen from the ranking tables that the excess in Seascale is apparent using either the 1971 or 1981 census data, suggesting that the excess is robust and not the result of large population changes.

This study has confirmed the apparent excess of lymphoid malignancy is Seascale when put into a wider context as suggested by the Black report. Other even more extreme examples, however, are seen in other wards. Caution is needed in the interpretation of these findings--some may be real and others may be artificial resulting from inadequate population data.

We are grateful to the North of England Children's Cancer Research Fund and the Cancer Research Campaign, Mrs Lorna More and Mrs Cora Christmas for

Table XI Poisson probability ranking: acute lymphoblastic leukaemia and non-Hodgkins lymphoma, 1971 census population data

\begin{tabular}{|c|c|c|c|c|}
\hline \multirow[b]{2}{*}{ Ward name } & \multicolumn{2}{|c|}{ Numbers } & \multicolumn{2}{|c|}{ Statistics } \\
\hline & $P$ & $C$ & Rate $^{\star}$ & Probability \\
\hline $\begin{array}{l}\text { Aged } 0-24 \text { y, 1968-85: } \\
\text { Seascale, Copeland, Cumbria } \\
\text { Shaw, Oldham, Greater Manchester } \\
\text { No 1. Sedgefield, Durham } \\
\text { Egremont North, Copeland, Cumbria } \\
\text { Broughton, South Lakeland, Cumbria }\end{array}$ & $\begin{array}{r}860 \\
2174 \\
2221 \\
1492 \\
820\end{array}$ & $\begin{array}{l}6 \\
5 \\
2 \\
4 \\
3\end{array}$ & $\begin{array}{r}15 \cdot 0 \\
4 \cdot 9 \\
4 \cdot 8 \\
5 \cdot 8 \\
7 \cdot 8\end{array}$ & $\begin{array}{l}.0000041 \\
.0038713 \\
.0042324 \\
.0056286 \\
.0070098\end{array}$ \\
\hline $\begin{array}{l}\text { Aged 0-14 y, 1968-85: } \\
\text { Seascale, Copeland, Cumbria } \\
\text { No 1. Sedgefield, Durham } \\
\text { Shaw, Oldham, Greater Manchester } \\
\text { Broughton, South Lakeland, Cumbria } \\
\text { Birch Green, West Lancashire, Lancashire } \\
\text { Aged 15-24 y, 1968-85: }\end{array}$ & $\begin{array}{r}605 \\
1371 \\
1381 \\
525 \\
8\end{array}$ & $\begin{array}{l}6 \\
5 \\
5 \\
3 \\
1\end{array}$ & $\begin{array}{r}17 \cdot 8 \\
6 \cdot 5 \\
6 \cdot 5 \\
10 \cdot 3 \\
224 \cdot 3\end{array}$ & $\begin{array}{l}.0000015 \\
.0011558 \\
.0011931 \\
.0033590 \\
.0044492\end{array}$ \\
\hline $\begin{array}{l}\text { Longhorsley, Castle Morpeth, Northumberland } \\
\text { Derby, Bolton, Greater Manchester } \\
\text { No } 20 \text {. North Tyneside, Tyne and Wear (Camperdown) } \\
\text { Howletch, Easington, Durham } \\
\text { Pentrith South, Eden, Cumbria }\end{array}$ & $\begin{array}{r}123 \\
2255 \\
1579 \\
261 \\
281\end{array}$ & $\begin{array}{l}2 \\
5 \\
4 \\
2 \\
2\end{array}$ & $\begin{array}{r}47 \cdot 3 \\
6 \cdot 5 \\
7 \cdot 4 \\
22 \cdot 3 \\
20 \cdot 7\end{array}$ & $\begin{array}{l}\cdot 0008676 \\
\cdot 0012256 \\
\cdot 0023452 \\
\cdot 0037858 \\
\cdot 0043683\end{array}$ \\
\hline $\begin{array}{l}\text { Aged } 0-24 \text { y, 1968-76: } \\
\text { Seascale, Copeland, Cumbria } \\
\text { Whittingham, Alnwick, Northumberland } \\
\text { Pendleside, Pendle, Lancashire } \\
\text { Alston, Ribble Valley, Lancashire } \\
\text { No 4. Salford, Greater Manchester }\end{array}$ & $\begin{array}{r}605 \\
292 \\
393 \\
1431 \\
2913\end{array}$ & $\begin{array}{l}3 \\
2 \\
2 \\
3 \\
4\end{array}$ & $\begin{array}{r}14 \cdot 2 \\
27 \cdot 9 \\
20 \cdot 7 \\
8 \cdot 5 \\
5 \cdot 6\end{array}$ & $\begin{array}{l}\cdot 0013419 \\
\cdot 0024522 \\
\cdot 0043697 \\
\cdot 0055732 \\
.0062046\end{array}$ \\
\hline $\begin{array}{l}\text { Aged } 0-14 \text { y, 1968-76: } \\
\text { Seascale, Copeland, Cumbria } \\
\text { Whittingham, Alnwick, Northumberland } \\
\text { Alston, Ribble Valley, Lancashire } \\
\text { Prudhoe South, Tynedale, Northumberland } \\
\text { Pendleside, Pendle, Lancashire }\end{array}$ & $\begin{array}{l}605 \\
182 \\
868 \\
907 \\
257\end{array}$ & $\begin{array}{l}3 \\
2 \\
3 \\
3 \\
2\end{array}$ & $\begin{array}{l}16 \cdot 4 \\
36 \cdot 4 \\
11 \cdot 5 \\
11 \cdot 0 \\
25 \cdot 8\end{array}$ & $\begin{array}{l}\cdot 0008829 \\
\cdot 0014517 \\
\cdot 0024584 \\
\cdot 0027806 \\
\cdot 0028516\end{array}$ \\
\hline $\begin{array}{l}\text { Aged 15-24 y, 1968-76: } \\
\text { No 4. Salford, Greater Manchester } \\
\text { Great Moor, Stockport, Greater Manchester } \\
\text { Beechwood, Middlesbrough, Cleveland } \\
\text { Newcomen, Langbaurgh, Cleveland } \\
\text { Castle, Tynedale, Northumberland }\end{array}$ & $\begin{array}{r}1099 \\
1835 \\
885 \\
979 \\
100\end{array}$ & $\begin{array}{l}3 \\
3 \\
2 \\
2 \\
1\end{array}$ & $\begin{array}{l}16 \cdot 8 \\
10 \cdot 0 \\
13 \cdot 9 \\
12.5 \\
61 \cdot 4\end{array}$ & $\begin{array}{l}\cdot 0008365 \\
\cdot 0035630 \\
.0094440 \\
.0114409 \\
\cdot 0161570\end{array}$ \\
\hline
\end{tabular}

${ }^{\star}$ Incidence ratio rate
Table XII Cases of acute lymphoblastic leukaemia (ALL) and non-Hodgkins lymphoma (NHL) that occurred in Seascale between 1968 and fuly 1990 and population

\begin{tabular}{|c|c|c|c|}
\hline Year of diagnosis & \multicolumn{2}{|c|}{ Age at diagnosis $(y)$} & $\begin{array}{l}\text { Diagnosis } \\
\text { ALL }\end{array}$ \\
\hline $\begin{array}{l}1968 \\
1968 \\
1971 \\
1979 \\
1983 \\
1984 \\
1988^{\star}\end{array}$ & $\begin{array}{r}11 \\
4 \\
3 \\
5 \\
9 \\
1 \\
23\end{array}$ & & $\begin{array}{l}\text { ALL } \\
\text { ALL } \\
\text { ALL } \\
\text { ALL } \\
\text { NHL } \\
\text { NHL } \\
\text { NHL } \\
\end{array}$ \\
\hline $1988^{\star}$ & \multicolumn{3}{|c|}{ Population of Seascale } \\
\hline Census year & Age $0-14 y$ & Age 15-24 y & Total \\
\hline $\begin{array}{l}1971 \\
1981\end{array}$ & $\begin{array}{l}605 \\
411\end{array}$ & $\begin{array}{l}255 \\
339\end{array}$ & $\begin{array}{l}860 \\
750\end{array}$ \\
\hline
\end{tabular}

ॠNot included in present report.

their help with data from the children's cancer registries, and to Mrs Sandra Gravestock and the Mersey Cancer Registry for supply of data. Miss Caroline Fry and Mrs Jackie Colligan were involved in data collection. We are grateful to Drs P Hamilton, M Harris, A J Malcolm, H B Marsden, $H$ Reid, and M M Reid who reviewed the diagnostic material. Dr J M Birch is a Cancer Research Campaign Senior Research Fellow.

1 Black D. Investigation of the possible increased incidence of cancer in west Cumbria. London: HMSO, 1984.

2 Gardner MJ, Hall AJ, Downes S, Terrell JD. Follow-up study of children born to mothers resident in Seascale, wes Cumbria: birth cohort. BMF 1987; 295: 822-7.

3 Gardner MJ, Hall AJ, Downes S, Terrell JD. Follow up study of children born elsewhere but attending schools in Seascale, west Cumbria: schools cohort. BMF 1987; 295 819-22.

4 Gardner MJ, Snee MP, Hall AJ, Powell CA, Downes S, Terrel JD. Results of case-control study of leukaemia and lymphoma among young people near Sellafield nuclear plant in west Cumbria. BMf 1990; 300: 423-9.

5 Craft AW, Amineddine HA, Scott JES, Wagget J. The Northern children's malignant disease registry 1968-1982, incidence and survival. $\mathrm{Br} \mathcal{F}$ Cancer 1987; 56: 853-58.

6 Birch JM, Marsden HB, Morris-Jones PH, Pearson D, Blair $V$. Improvements in survival from childhood cancer: results of a population based study over 30 years. BMF 1988; 296

7 Nwene U, Smith A. Assessing completeness of cancer registration in north western region of England by a method of independent comparison. Br F Cancer 1982; 46: 635-9. 8 World Health Organisation. International classification of diseases for oncology. Geneva: WHO, 1976.

9 Gardner MJ. Review of reported increases of childhood cancer rates in the vicinity of nuclear installation in the United Kingdom. F R Statistical Soc A 1989: 152: 307-25.

10 Wakeford R, Binks K, Wilkie D. Childhood leukaemia and nuclear installations. $\mathcal{F} R$ Statistical Soc $A$ 1989: 152: 61-86.

11 Committee on Medical Aspects of Radiation in the Environment. Investigation of the possible increased incidence of leukaemia in young people near Dounreay nuclear establishment, Caithness, Scotland. London: HMSO, 1988

12 Committee on Medical Aspects of Radiation in the Environment. Report on the incidence of childhood cancer in the west Berkshire and north Hampshire area, in which are sim the west Berkshire and north Hampshire area, in which are situated the Royal Ordnance Factory, Burghfield. London: HMSO, the Royal
1989.

13 Greaves MF. Speculations on the cause of childhood ALL Leukaemia 1988; 2: 120

14 Openshaw S, Craft AW, Charlton M, Birch JM. Investigation of leukaemia clusters by use of a geographical analysis machine. Lancet 1988; i: 272-3.

15 Besag J, Newell J. The detection of clusters in rare diseases. $f$ $R$ Statistical Soc $A$ 1991; 154: 143-55.

16 Stone RA. Investigations of excess environmental risks around putative sources: statistical problems and a proposed test. Statistics in Med 1988; 7: 649-60.

17 Cuzick J, Edwards R. Spatial clustering for inhomogeneous populations (with discussion). J R Statistical Soc B 1990; 53: 73-104. 